\title{
Analisa Kekuatan Tarik dan Tekuk pada Komposit Fiberglas-Polyester Berpenguat Serat Gelas dengan Variasi Fraksi Volume Serat
}

\author{
Siti Auliana Rahmawaty ${ }^{1, a}$, Ade Wahyu Yusariarta Putra Parmita ${ }^{1, b)}$, Andromeda Dwi \\ Laksono $^{1, \mathrm{c})}$
}

1,Program Studi Teknik Material dan Metalurgi, Institut Teknologi Kalimantan, Jl. Soekarno-Hatta KM. 15, Karang Joang, Balikpapan, Kalimantan Timur, 76127

a) $\underline{06171071 @ \text { student.itk.ac.id, }},{ }^{\text {b) }}$ adewahyu27@lecturer.ac.id (corresponding author), ${ }^{\text {c) }}$ andromeda@ lecturer.ac.id

\begin{abstract}
Abstrak
Kapal yang banyak digunakan di Indonesia yaitu kapal ikan berbahan dasar fiberglass yang harganya murah, serta proses pembuatannya sederhana dan mudah. Kapal ikan fiberglass merupakan jenis kapal komposit karena terdiri dari pengikat (matrix) berupa polyester dan penguat (reinforcement) dari fiberglass. Namun kapal jenis ini sering mengalami kerusakan akibat dari pembeban yang diterima seperti hantaman ombak yang terus menerus sehingga dapat menyebabkan terjadinya patahan. Salah satu penyebab ketidak mampuan kapal dalam menahan beban yaitu karena tidak memenuhi standar BKI terutama pada desain konstruksi, fraksi volume bahan dan proses laminasi pada lambung kapal ikan fiberglass. Untuk meminimalisir hal itu, dilakukan penelitian dengan memvariasi fraksi volume serat fiberglass dengan metode hand lay up dan orientasi arah serat $0^{\circ}$ dengan tujuan untuk meningkatkan kekuatan tekuk dan tarik sehingga mampu memenuhi standar yang telah ditetapkan. Dari hasil pengujian, diperoleh fraksi volume serat yang optimum yaitu 12,5\% dengan kekuatan tarik sebesar 79,31 MPa dan kekuatan tekuk sebesar 129,38 MPa serta perkiraan kandungan void-nya yaitu 1,84 \%. Hasil yang diperoleh kurang 19\% untuk kekuatan tarik dan 13\% untuk kekuatan tekut dari standar BKI, namun terdapat indikasi bahwa jika fraksi volume serat yang digunakan lebih dari 12,5\% maka akan bisa memenuhi standar BKI.
\end{abstract}

Kata kunci: fiberglass, komposit, polyester

\begin{abstract}
Boats that are often found in Indonesia are fishing boats made of fiberglass. The price of fishing these boats is cheap and the shipbuilding process is simple and easy. A fiberglass boat is a type of composite ship because it consists of polyester as a matrix and fiberglass as a reinforcement. However, the boat often gets damaged caused by the load that is received by a ship, like a continuous wave. Meanwhile, many of the ships found do not pass the BKI standards, especially the design, volume fraction of fiber, and lamination, so that the ships are not compatible to resist the load. To solve this problem, research was conducted by varying the volume fraction of fiberglass with the hand lay-up method and the orientation of the fiber is $0^{\circ}$. The purpose of this study is to improve the mechanical properties especially tensile and bending strength. The results show that the optimum fiber volume fraction was $12,5 \%$ with the tensile strength of 79.31 $\mathrm{MPa}$, the bending strength of $129.38 \mathrm{MPa}$, and the estimated void content was 1,84\%. The optimum results did not pass the BKI standards, the result is $19 \%$ for tensile strength and 14\% for the banding strength less than the BKI Standards. However, there are promising indications to pass the BKI standard if the volume fraction of fiber used is more than $12.5 \%$.
\end{abstract}

Keywords: composite, fiberglass, polyester

\section{PENDAHULUAN}

Kapal merupakan alat transportasi laut yang digunakan untuk mengangkut barang atau penumpang dari satu tempat ke tempat lain, contohnya yaitu kapal perikanan. Salah satu jenis material kapal yaitu komposit. Komposit merupakan gabungan bahan utama (matriks) dan jenis penguat (reinforcement) untuk mendapatkan gabungan sifat dari 2 bahan tersebut. Pembuatan kapal berbahan dasar komposit berpenguat fiberglass saat ini sedang banyak diminati karena ketersediannya yang cukup juga bersifat ringan. Adanya beban dari hantaman ombak atau gelombang air laut mengakibatkan terjadinya tegangan. Terjadinya tegangan dari ombak laut yang berlebih mengakibatkan kerusakan pada kapal. Hal ini karena desain konstruksi dan proses laminasi pada lambung kapal fiberglass tidak mengacu pada suatu standar [1] seperti komposisi dan jumlah lapisan. Penelitian lanjutan dilakukan [2], hasil pengujian beberapa sampel laminasi, mengindikasikan bahwa, sekitar 30 persen kapal fiberglass yang dibangun selama ini dan yang beroperasi 
di dalam negeri tidak memenuhi kekuatan konstruksi sesuai persyaratan BKI (Biro Klasifikasi Indonesia) tarik $98 \mathrm{MPa}$ dan tekuk $150 \mathrm{MPa}$, terdapat data salah satu sampel kapal yang tidak memenuhi standar yaitu kekuatan tarik sebesar $75 \mathrm{MPa}$ dan kekuatan tekuk sebesar $138 \mathrm{MPa}$.

Guna mendapat nilai kekuatan tarik komposit yang tinggi, salah satu hal yang perlu diperhatikan yaitu komposisi komposit dalam hal ini fraksi volume serat. Hasil penelitian [3], menyimpulkan bahwa semakin banyak jumlah lapisan, maka komposisi atau fraksi volume serat gelas akan semakin meningkat sehingga kekuatannya semakin besar karena pendistribusian beban ke spesimen akan lebih banyak ke jumlah lapisannya. Selain pada komposisi komposit, jenis dari serat juga mempengaruhi besar kekuatan tariknya. Kekuatan komposit akan semakin rendah bila sudut orientasi serat semakin besar menuju $90^{\circ}$ [4].

Berdasarkan uraian tersebut, untuk mendapatkan hasil yang optimum maka dilakukan penelitian komposit fiberglasspolyester dengan menambahkan variasi fraksi volume serat dan menggunakan metode hand lay up serta orientasi serat $0^{\circ}$. Dengan penambahan fraksi volume serat harapannya akan mendapatkan kombinasi sifat kekuatan tinggi dan berat jenis yang ringan, sehingga hasil kekuatan tarik dan tekan sesuai dengan standar.

\section{LANDASAN TEORI}

\section{A. Komposit}

Komposit berasal dari kata kerja "to compose" yang berarti menyusun atau menggabungkan [5]. Komposit adalah gabungan dari 2 atau lebih material yang memiliki sifat berbeda untuk mendapatkan gabungan dari kedua sifat material tersebut [6]. Komposit terdiri dari pengikat (matriks) dan penguat (reinforcement) yang ditambahkan untuk mengkombinasikan sifat mekanik. Dalam perkembangan teknologi komposit mengalami kemajuan yang sangat pesat di karenakan ke istimewaan sifat yang terbarukan dan juga memiliki kekuatan yang tinggi, kekakuan, ketahan panas yang tinggi, korosi dll [5].

Bahan komposit serat mempunyai keunggulan yang utama yaitu kuat (strong), tangguh (stiff), dan lebih tahan terhadap panas pada saat didalam matriks [7]. Pemilihan material matriks biasanya mempertimbangkan sifatsifatnya, yaitu tahan terhadap panas, tahan cuaca yang buruk dan tahan terhadap goncangan. Bahan matriks dapat berupa polimer, keramik, logam atau karbon. [8]

Jenis komposit serat terbagi menjadi 4 macam yaitu:

1. Continuous fiber composite (komposit yang diperkuat dengan serat kontinu)

2. Woven fiber composite (komposit yang diperkuat dengan serat anyaman)

3. Chopped fiber composite (komposit yang diperkuat dengan serat pendek/acak)

4. Hybrid composite (komposit yang diperkuat dengan serat kontinu dan serat acak).

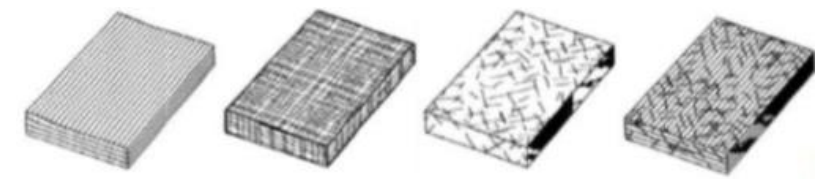

Gambar 1. Jenis komposit serat [8]

Matriks polimer digunakan karena memiliki sifat ulet, densitas rendah, tahan korosi serta fabrikasi mudah. Paling umum digunakan adalah jenis epoksi, polyester, fenolik, dan lain-lain. PMC terbagi dua berdasarkan pengaruh temperatur pada jenis polimer yaitu termoplastik dan termoset. Termoplastik memiliki sifat ikatan linier atau bercabang dengan temperatur leleh rendah namun dapat dibentuk ulang dan lemah. Termoset memiliki sifat ikatan silang dengan temperatur leleh tinggi namun tidak dapat dibentuk ulang dan kuat. Dua jenis polimer tersebut tentu proses manufaktur komposit akan berbeda perlakuan [9].

\section{B. Fiberglass Roving}

Biayanya yang murah, kekuatan tarik tinggi, ketahanan benturan tinggi, dan ketahanan kimia yang baik, fiberglass digunakan secara luas dalam aplikasi komposit. Meskipun ada banyak jenis fiberglass, tiga yang paling umum digunakan dalam komposit adalah $E$ glass, S-2 glass, dan kuarsa. E-glass adalah yang paling umum dan paling murah, memberikan kombinasi yang baik. [10]
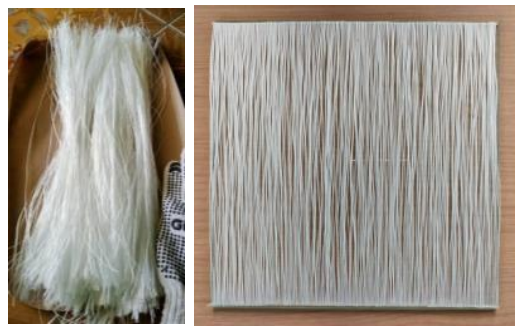

Gambar 2. Fiberglass roving

Keunggulan fiberglass terletak pada perbandingan harga dan performance yaitu biaya produksi rendah, proses produksi sangat sederhana, serat gelas banyak digunakan di industri-industri otomotif seperti pada body kendaraan [11].

Tabel 1. Sifat dari e-glass [12]

\begin{tabular}{cc}
\hline Sifat Mekanik dan Fisik & E-Glass \\
\hline Massa Jenis (g/cm3) & 2.54 \\
Kekuatan Tarik (Gpa) & 3.45 \\
Kekakuan Tarik (Gpa) & 72.4 \\
Regangan Saat Gagal \% & 4.8 \\
\hline
\end{tabular}

\section{Polyester}

Matriks polimer yang sering dipakai untuk komposit yaitu jenis thermoset yang berbentuk resin. Resin yang sering digunakan yaitu epoxy dan polyester. Polyester 
berupa resin cair dengan viskositas yang relatif rendah, mengeras pada suhu kamar dengan penggunaan katalis dan harganya relatif lebih terjangkau dari pada epoxy.

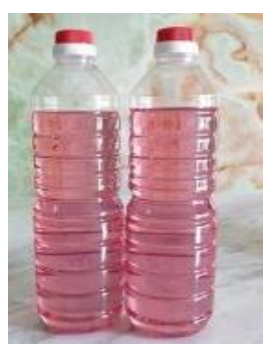

Gambar 3. Resin polyester

Resin polyester merupakan resin yang paling banyak digunakan dalam berabagai aplikasi yang menggunakan resin termoset, baik itu secara terpisah maupun dalam bentuk materal komposit.

Tabel 2. Sifat dari polyester [13]

\begin{tabular}{cc}
\hline Sifat Mekanik dan Fisik & Polyester \\
\hline Massa Jenis (g/cm3) & 1.09 \\
Kekuatan Tarik (MPa) & 40 \\
Kekakuan Tarik (Gpa) & 3.3 \\
Kekuatan Tekuk (MPa) & 45 \\
Regangan Saat Gagal \% & 1 \\
\hline
\end{tabular}

\section{Katalis}

Katalis adalah bahan pemicu (initiator) yang berfungsi untuk mempersingkat proses curing pada temperatur ruang. Komposisi katalis pada komposit harus sangat diperhatikan. Komposit dengan kadar katalis yang terlalu sedikit akan mengakibatkan proses curing yang terlalu lama. Apabila pada proses terjadi kelebihan katalis, maka akan menimbulkan panas yang berlebihan sehingga akan merusak produk. [14]

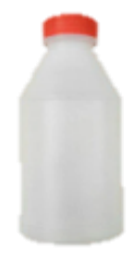

Gambar 4. Katalis

Katalis yang digunakan dalam penelitian ini adalah Metyl Etyl Keton Peroksida (MEKPO) yaitu bahan kimia yang dikenal dengan sebutan katalis. Fungsi dari katalis adalah mempercepat proses pengeringan (curing) pada bahan matriks suatu komposit. Semakin banyak jumlah katalis yang dicampurkan pada cairan matriks akan mempercepat proses laju pengeringan [15].
Katalis digunakan untuk mempercepat pengerasan resin pada suhu yang tinggi. Semakin banyak katalis maka reaksi pengerasan resin akan semakin cepat tetapi terlalu banyak katalis bisa membuat resin getas dan rapuh. Oleh karena itu pemakaian katalis dibatasi sampai $1 \%$ dari volume resin.

\section{E. Hand Lay Up}

Hand lay-up merupakan metode yang paling sederhana dan murah dibandingkan dengan metode manufaktur komposit lainnya. Adapun proses dari pembuatan dengan metode ini yaitu dengan cara menuangkan resin kedalam serat, partikel atau lembaran, dan kemudian memberi tekanan sekaligus meratakannya menggunakan roll atau kuas. Proses tersebut dilakukan berulang-ulang hingga ketebalan yang diinginkan tercapai. Pada proses ini resin langsung berkontak dengan udara dan biasanya proses pencetakan dilakukan pada temperatur kamar. Pada metode hand lay up ini resin yang paling banyak di gunakan adalah polyester dan epoxy.

Kelebihan penggunaan metode ini yaitu, [16]

1. Mudah dilakukan

2. Cocok digunakan untuk komponen yang besar.

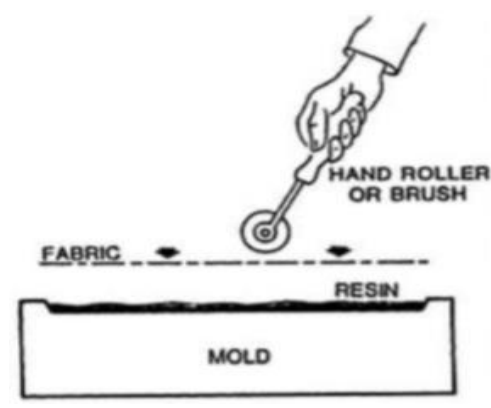

Gambar 5. Metode hand lay up [16]

\section{F. Pengujian Tarik (Tensile Test)}

Uji tarik merupakan suatu metode yang digunakan untuk menguji kekuatan suatu bahan atau material dengan cara memberikan beban gaya pada satu sumbu [17].

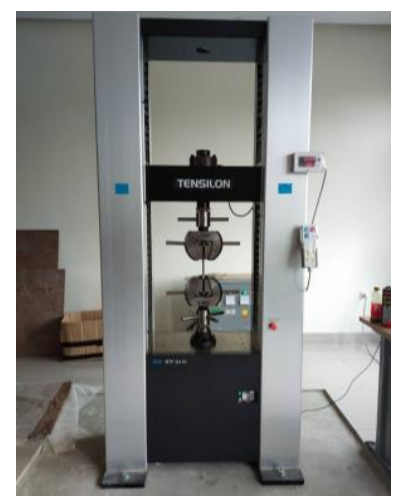

Gambar 6. Mesin uji tarik 
Kekuatan tarik komposit ini mengacu pada standar BKI. Alat yang digunakan untuk menguji kekuatan tarik komposit ini menggunakan Universal Testing Machine. Proses penarikan suatu bahan akan diketahui bagaimana bahan tersebut bereaksi terhadap gaya tarikan dan dapat diketahui pertambahan panjangnya. [18]

Hasil dari pengujian tarik berupa grafik hubungan beban dan pertambahan panjang. Berikut adalah rumus menghitung kekuatan tarik dan regangan dari pengujian tarik sebagai berikut:

1. Tensile strength atau kekuatan tarik dapat didefinisikan sebagai gaya per unit luas material yang menerima gaya tersebut.

$$
\sigma=\frac{F}{A_{o}}
$$

di mana $\mathrm{F}$ adalah beban sesaat yang diterapkan tegak lurus terhadap potongan melintang spesimen, dalam satuan newton $(\mathrm{N})$ atau gaya pound (lbf), dan Ao adalah luas penampang asli sebelum beban diterapkan (m2 atau in.2). Satuan tegangan teknik megapascal, $\mathrm{MPa}(\mathrm{SI})$ (di mana $1 \mathrm{MPa}=106 \mathrm{~N} / \mathrm{m} 2$ ), dan pound gaya per inci persegi, psi.

2. Tensile strain adalah ukuran perubahan panjang suatu material setelah dilakukan uji tarik, sehingga dari hasil pengujian tarik dapat digunakan untuk mencari nilai regangan dari suatu material.

$\varepsilon=\frac{\Delta L}{L_{0}}=\frac{l_{i-} l_{o}}{l_{o}}$

di mana lo adalah panjang awal sebelum beban diterapkan dan li adalah panjang sesaat. Kadangkadang kuantitas li - lo dilambangkan sebagai $\Delta \mathrm{L}$ dan merupakan pertambahan panjang akibat deformasi. Regangan teknik tidak memiliki satuan, tetapi meter per meter atau inci per inci sering digunakan, nilai regangan jelas tidak tergantung pada sistem unit. Kadang-kadang regangan juga dinyatakan sebagai persentase, di mana nilai regangan dikalikan dengan 100 [18].

3. Modulus elastisitas (Young Modulus) adalah perbandingan antara tegangan (stress) dengan regangan (strain).

$$
E=\frac{\sigma}{\varepsilon}
$$

dimana $\mathrm{E}$ adalah modulus elastisitas $(\mathrm{MPa}), \sigma$ adalah tegangan $(\mathrm{MPa})$ dan $\varepsilon$ adalah regangan.

\section{G. Pengujian Tekuk (Bending Test)}

Pengujian tekuk merupakan pengujian yang dilakukan pada suatu material untuk mengetahi karakteristik tekuk dari material tersebut. Salah satu metode dari pengujian tekuk yaitu three point bending. Pengujian three point bending dilakukan untuk mengetahui kekuatan tekuk (flexural stiffness) komposit. Pengujian ini dilakukan dengan cara sebuah spesimen berbentuk batang disangga pada kedua sisinya, kemudian diberikan beban diantara kedua penyangga tersebut sampai spesimen mengalami patah.

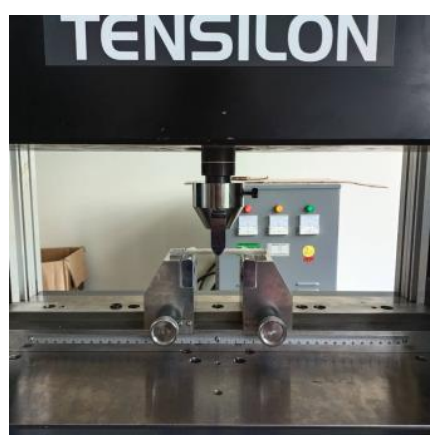

Gambar 7. Mesin uji tekuk

Idealnya spesimen uji tekuk akan mengalami kegagalan berupa patah atau fracture akibat adanya beban geser (shear). Pada bagian atas spesimen akan mengalami beban tekan dan pada bagian bawah spesimen akan mengalami beban tarik.
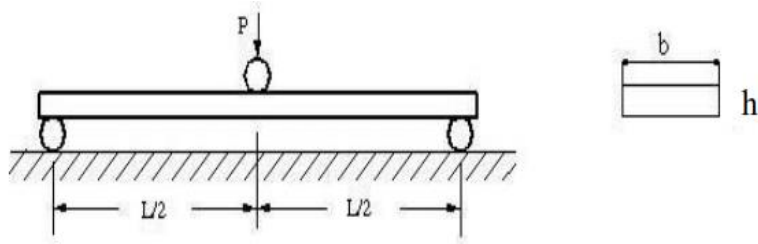

Gambar 8. Pembebanan pada pengujian three-point bending [19]

Nilai kekuatan tekuk dapat dihitung dengan persamaan:

$\sigma_{b}=\frac{M c}{I}$

Dimana M, I, dan c dapat dihitung dengan persamaan sebagai berikut:

$$
\begin{aligned}
& M=\frac{P L}{8} \\
& I=\frac{b d^{3}}{12} \\
& c=d
\end{aligned}
$$

Substitusikan persamaan 5, 6 dan 7 ke dalam persamaan 4.dan didapatkan persamaan 8. Persamaan kekuatan tekuk [19],

$\sigma_{b}=\frac{3 P L}{2 b d^{2}}$

dimana: 


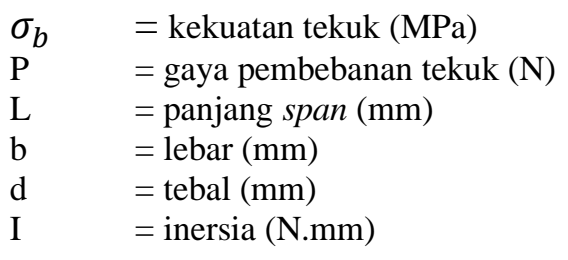

\section{H. Perhitungan Fraksi Volume dan Berat}

Perhitungan teori untuk mengetahui kekuatan dan modulus dari komposit didasarkan pada fraksi volume dari material yang ada didalam komposit. Perhitungannya menggunakan hukum pencampuran (rule of mixtures). Berikut adalah cara perhitungan fraksi volume dengan menggunakan rumus dari fraksi berat [12].

$V_{f}=\frac{W_{f} / \rho_{f}}{W_{f} / \rho_{f}+W_{m} / \rho_{m}}$

$V_{m}=\frac{W_{m} / \rho_{m}}{W_{m} / \rho_{m}+W_{f} / \rho_{f}}$

$v_{c}=W_{m} / \rho_{m}+W_{f} / \rho_{f}$

$W_{f} / \rho_{f}=v_{f}$

$W_{m} / \rho_{m}=v_{m}$

dimana:

$V_{f} \quad=$ fraksi volume serat $(\%)$

$V_{m} \quad=$ fraksi volume matriks $(\%)$

$W_{f} \quad=$ fraksi berat serat $(\%)$

$\rho_{f} \quad=$ massa jenis serat $\left(\mathrm{g} / \mathrm{cm}^{3}\right)$

$W_{m} \quad=$ fraksi berat matriks $(\%)$

$\rho_{m} \quad=$ massa jenis matriks $\left(\mathrm{g} / \mathrm{cm}^{3}\right)$

$v_{f} \quad=$ volume serat $\left(\mathrm{cm}^{3}\right)$

$v_{m} \quad=$ volume matriks $\left(\mathrm{cm}^{3}\right)$

$v_{c} \quad=$ volume komposit $\left(\mathrm{cm}^{3}\right)$

\section{Perhitungan Void}

Perhitungan kadar void (rongga kosong atau udara yang terjebak) dilakukan dengan tujuan untuk mengetahui kandungan void pada suatu komposit. Perhitungan kadar void mengacu pada standar ASTM D2734-94 Pengujian ini diawali dengan menghitung fraksi berat serat dan resin. Setelah didapatkan fraksi berat, maka dapat dihitung densitas teori dari komposit dengan persamaan sebagai berikut, [20]

$$
T d=\frac{100}{\frac{R}{D}+\frac{r}{d}}
$$

dimana:

$$
\begin{array}{ll}
\mathrm{Td} & =\text { Teori densitas }\left(\mathrm{gr} / \mathrm{cm}^{3}\right) \\
\mathrm{R} & =\text { Fraksi berat matriks }(\%) \\
\mathrm{D} & =\text { Massa jenis matriks }\left(\mathrm{gr} / \mathrm{cm}^{3}\right) \\
\mathrm{r} & =\text { Fraksi berat serat }(\%) \\
\mathrm{d} & =\text { Massa jenis serat }\left(\mathrm{gr} / \mathrm{cm}^{3}\right)
\end{array}
$$

Setelah didapatkan nilai densitas teori, maka dilakukan perhitungan densitas komposit (Md).

$$
\begin{aligned}
& M d=\frac{m}{v} \\
& \text { dimana: } \\
& \text { Md } \quad=\text { Teori komposit }\left(\mathrm{gr} / \mathrm{cm}^{3}\right) \\
& \mathrm{m} \quad=\text { Berat komposit }(\mathrm{gr})
\end{aligned}
$$

Kemudian, kandungan void dalam komposit dapat dihitung dengan menggunakan rumus berikut:

$$
V=100 \frac{(T d-M d)}{T d}
$$

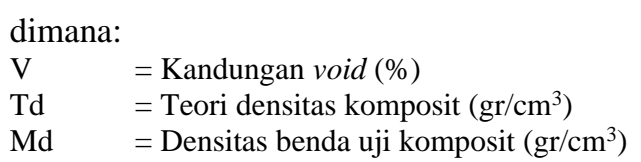

\section{METODE PENELITIAN/EKSPERIMEN}

\section{A. Alat dan Bahan}

Alat-alat yang digunakan pada penelitian ini terbagi menjadi dua, yaitu peralatan yang digunakan untuk persiapan sampel dan peralatan yang digunakan untuk pengujian sampel. Peralatan persiapan sampel antara lain timbangan digital, cetakan logam, roll dan kuas, gerinda, kamera makro (USB Digital Microscope). Peralatan pengujian sampel terdiri dari dua pengujian, yaitu mesin uji tarik dan tekuk (Tensilon Machine RTF-2410). Bahan yang akan digunakan pada penelitian ini yakni serat gelas roving, polyester (Unsaturated Polyester Resin) dan katalis (Metyl Etyl Keton Peroksida), minyak resin (mold release), dan plastisin.

\section{B. Prosedur Pembuatan Komposit}

Sebelum pembuatan komposit, pertama dilakukan pembuatan bahan serat serat dengan arah orientasi $0^{\circ}$. kedua, dilakukan pembuatan komposit dengan menggunakan fraksi volume serat (Vf) serat 8,9\%, 10,7\% dan $12,5 \%$.

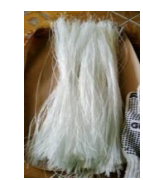

Siapkan serat yang searah

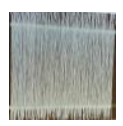

Hasil serat yang telah
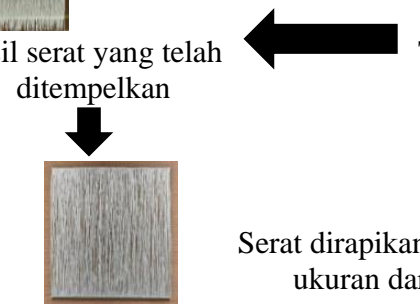

beri solasi dikedua sisi

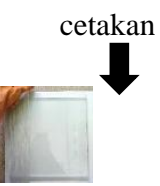

Tempelkan serat pada cetakan

Serat dirapikan menyesuaikan ukuran dari cetakan 
Perbandingan matriks yang digunakan $99,3 \%$ resin dan $0,7 \%$ katalis. penimbangan fraksi volume serat dan matriks sesuai dengan hasil perhitungan yaitu fraksi volume serat $8,9 \%$ sebanyak 56,7 gr dan $91,9 \%$ matriks sebesar 248,24 gr, fraksi volume serat $10,7 \%$ sebanyak 68,04 gr dan $89,3 \%$ matriks sebesar 243,34 gr, fraksi volume serat $12,5 \%$ sebanyak 79,38 gr dan $87,5 \%$ matriks sebesar 238,44 gr.

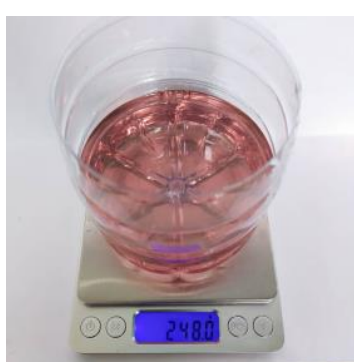

(a)

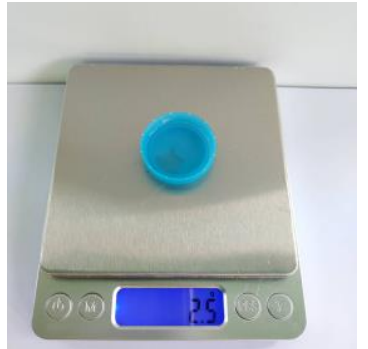

(b)
Gambar 10. Proses penimbangan (a) polyester dan (b) katalis

Hal pertama yang dilakukan sebelum pembuatan komposit yaitu menyiapkan cetakan yang telah dibersihkan. Kemudian, menutup sisi cetakan dengan lakban kertas agar resin tidak keluar dari sisi bawah cetakan. Setelah itu, melakukan pelapisan cetakan menggunakan mold release dengan menggunakan kuas agar komposit mudah dipisahkan atau dilepaskan dari cetakan. Pembuatan komposit dengan tahapan pertama yaitu meletakkan lembar serat pertama kemudian menuangkan resin ke cetakan. Lalu resin diratakan dengan menggunakan roll dilanjutkan dengan pemberian lembar serat yang kemudian diratakan menggunakan roll lagi. Lalu, lakukan penuangan resin dan penambahan serat berulang hingga mencapai jumlah lembar serat dan ketebalan yang ditentukan. Setelah mencapai jumlah lembar serat yang ditentukan, komposit didiamkan selama 2 jam. Kemudian setelah 2 jam, komposit ditutup dengan kaca agar permukaannya merata. Komposit ditunggu hingga kering selama 24 jam.
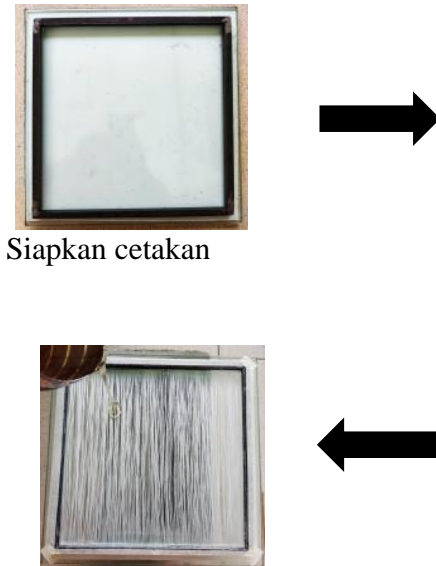

Tuang resin dengan hati-hati
Siapkan cetakan

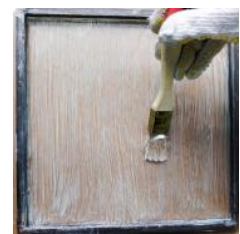

Beri mold release

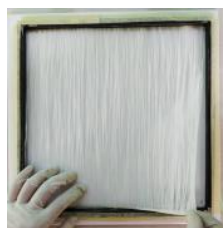

Letakan serat lapis 1
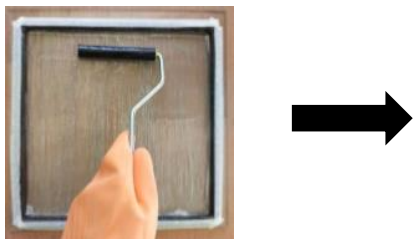

Ratakan resin dengan roll lakukan berulang dari tahap peletakan serat hingga mencapai jumlah serat yang ditentukan
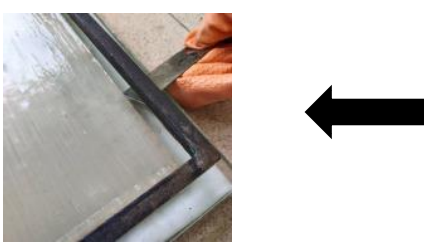

Setelah kering, cetakan dilepas dari alas cetakan

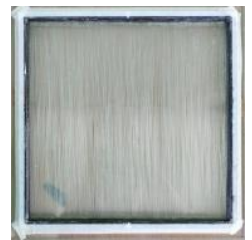

Diamkan komposit selama 2 jam
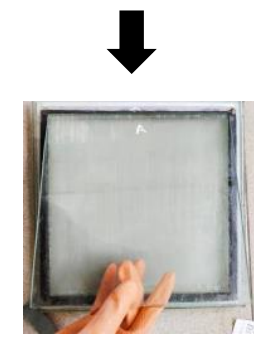

ditutup selama 24 jam agar permukaan rata

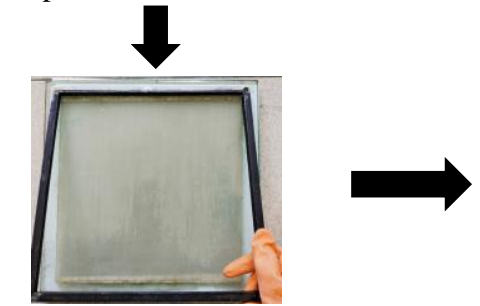

Cetakan diangkat hingga terlepas dari komposit

Komposit siap diukur untuk dipotong menjadi beberapa spesimen
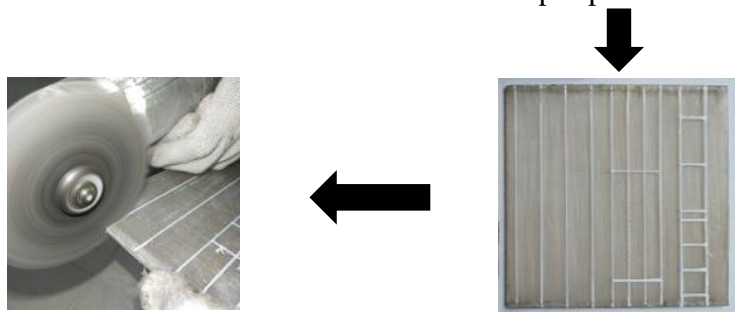

Komposit dipotong menjadi beberapa spesimen sebagai bahan

Komposit siap dipotong uji

Gambar 11. Pembuatan komposit dan pemotongan komposit

Setelah komposit dikeringkan selama 24 jam, komposit dilepas dari cetakan dengan menggunakan kapi. Lalu komposit diukur sesuai dengan standar BKI. Terakhir, komposit dipotong sesuai ukuran.

\section{Prosedur Pengujian Tarik}

Pengujian tarik bertujuan untuk mengetahui kekuatan tarik. Pengujian ini memerlukan sampel dengan dimensi yang sesuai dengan standar BKI. 


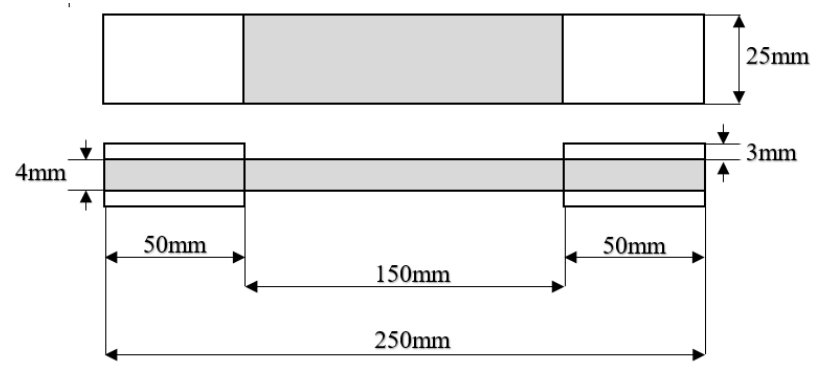

Gambar 12. Spesimen uji tarik [21]

Tahapan pengujian tarik yaitu:

1. Melakukan preparasi sampel yang akan diuji tarik yang sudah dipotong dan sesuai dengan standar.

2. Melakukan finishing dengan cara pengamplasan dan pengukuran sampel.

3. Melakukan pengujian tarik perlahan hingga spesimen patah dengan mesin uji tarik untuk mengetahui kekuatan tariknya.

4. mengamati beban dan titik UTS serta pertambahan panjang sampel.

5. Pengujian dilakukan sebanyak tiga kali pengulangan setiap variable.

\section{Prosedur Pengujian Tekuk}

Pengujian tekuk bertujuan untuk mengetahui kekuatan tekuk. Pengujian ini memerlukan sampel dengan dimensi yang sesuai dengan standar BKI.

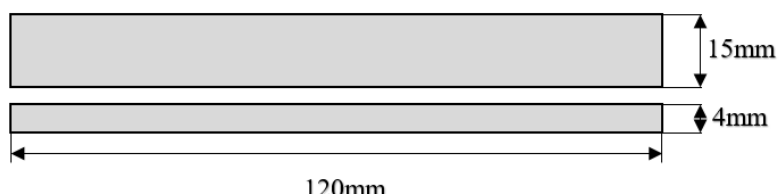

Gambar 13. Spesimen uji tarik [21]

Tahapan pengujian tekuk yaitu:

1. Melakukan preparasi sampel yang akan diuji tekuk yang sudah dipotong dan sesuai dengan standar.

2. Melakukan finishing dengan cara pengamplasan dan pengukuran sampel.

3. Melakukan pengujian tekuk dengan mesin uji tekuk untuk mengetahui kekuatan tekuknya. Spesimen diletakkan pada titik tengah alat uji.

4. Mengamati maximum stress dan beban pada sampel.

5. Pengujian dilakukan sebanyak tiga kali pengulangan setiap variable.

\section{E. Prosedur Perhitungan Void}

Pengujian ini dilakukan untuk mengetahui kadar void yang ada pada komposit. Pengujian ini mengacu pada standar ASTM D2734-94 dan sampel yang digunakan yaitu spesimen uji tekuk.

Tahapan perhitungan kadar void yaitu:

1. Mencari nilai densitas matriks dan serat yang digunakan
2. Menghitung nilai fraksi berat dari resin dan matriks pada komposit

3. Menghitung densitas teori dengan cara memasukkan nilai-nilai yang ada dengan rumus yang ada pada nomor 14

4. Menghitung densitas komposit yang akan diuji

5. Menghitung kandungan void dengan dengan menggunakan rumus yang ada pada nomor 16

6. Pengujian dilakukan sebanyak tiga kali pengulangan setiap variable.

\section{HASIL DAN PEMBAHASAN}

A. Pengamatan Makro

Komposit yang akan diuji menggunakan variasi fraksi volume serat $8,9 \%, 10,7 \%$ dan, $12,5 \%$ serta persentase resin dan katalis sebesar 99,3\%: 0,07\% dari jumlah matriks. Orientasi serat satu arah 0 derajat dengan menggunakan metode hand lay up. Pengujian komposit diurutkan dari spesimen kontrol polyester, dilanjutkan spesimen dengan fraksi volume serat $8,9 \%$, kemudian spesimen fraksi volume serat $10,7 \%$ dan terakhir spesimen fraksi volume serat $12,5 \%$. Sebelum dilakukannya pengujian, spesimen komposit dilakukan pengamatan secara visual baik dengan mata maupun dengan bantuan kamera makro.

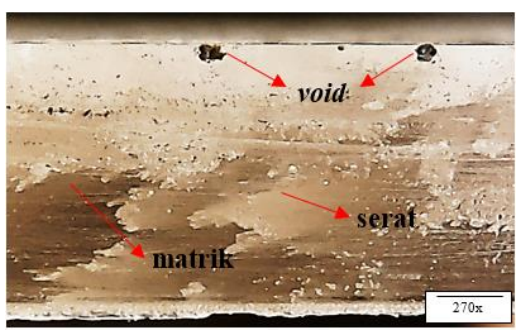

(a)

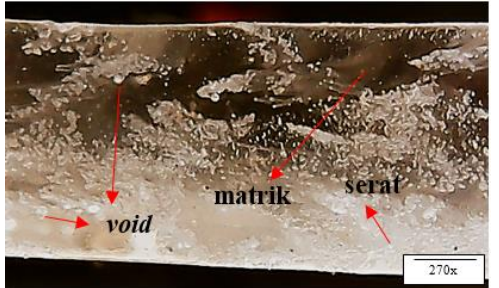

(b)

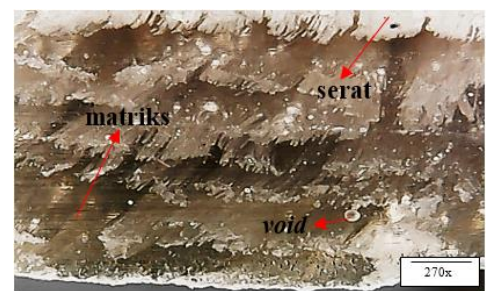

(c)

Gambar 14. Foto makro komposit (a) Vf $8,9 \%$, (b) Vf 10,7\%, (c) Vf $12,5 \%$

Gambar 14 menjelaskan bahwa komposit fiberglasspolyester berpenguat serat gelas yang terdiri atas matriks dan serat gelas serta terlihat juga ikatan antar 
serat dan matriks terikat dengan baik karena tidak terdapat delaminasi dan debonding sehingga hal ini menunjukkan bahwa penelitian komposit fiberglasspolyester berpenguat serat gelas telah berhasil dibuat dengan baik walaupun masih terdapat void yang terlihat pada komposit yang dibuat. Untuk mengetahui pengaruh adanya void, maka akan dilakukan uji tarik dan uji tekuk.

\section{B. Perhitungan Void}

Perhitungan void ini diawali dengan menghitung fraksi berat serat dan resin. Pengujian dilakukan sebanyak tiga kali pengulangan setiap variable. Setelah didapatkan fraksi berat, maka dapat dihitung densitas teori dari komposit sesuai dengan rumus nomor 14. Setelah dilakukan perhitungan, didapatkan hasil perhitungan dalam bentuk diagram batang.

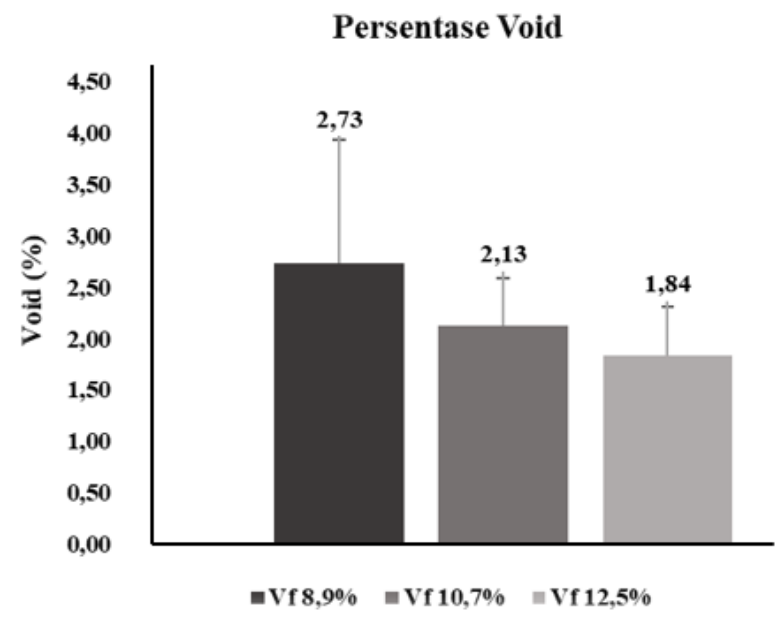

Gambar 15. Persentase void komposit

Void terbentuk karena resin tidak mampu mengisi celah kosong sehingga mengakibatkan timbulnya gelembung udara yang kemudian terjebak di dalam komposit. Kadar void yang diprediksikan pada komposit akan mempengaruhi kekuatan komposit. Yang dimana semakin tinggi kadar void, maka kekuatan komposit akan menurun [22]. Dari hasil data persentase void, terlihat bahwa semakin meningkat fraksi volume serat maka persentase kadar void semakin menurun. Hal ini dipengaruhi beberapa faktor seperti proses pengadukan matriks dan proses penekanan pada saat manufaktur hand lay up. Void dapat timbul saat proses pengadukan resin dan katalis karena adanya udara yang masuk dalam campuran dan membentuk gelembung udara [23]. Pada proses hand lay up, kecepatan dan tekanan yang diberikan untuk meratakan resin tidak dapat dikontrol [24] sehingga keberadaan void tidak dapat dihindari.

\section{Pengujian Tarik}

Hasil data dari mesin uji tarik selanjutnya dihitung untuk mencari nilai tegangan tarik, regangan dan modulus elastisitas dari setiap spesimen uji. Pengujian dilakukan sebanyak tiga kali pengulangan setiap variable. Pada gambar 16, didapatkan hasil nilai kekuatan tarik komposit rata-rata mengalami peningkatan.

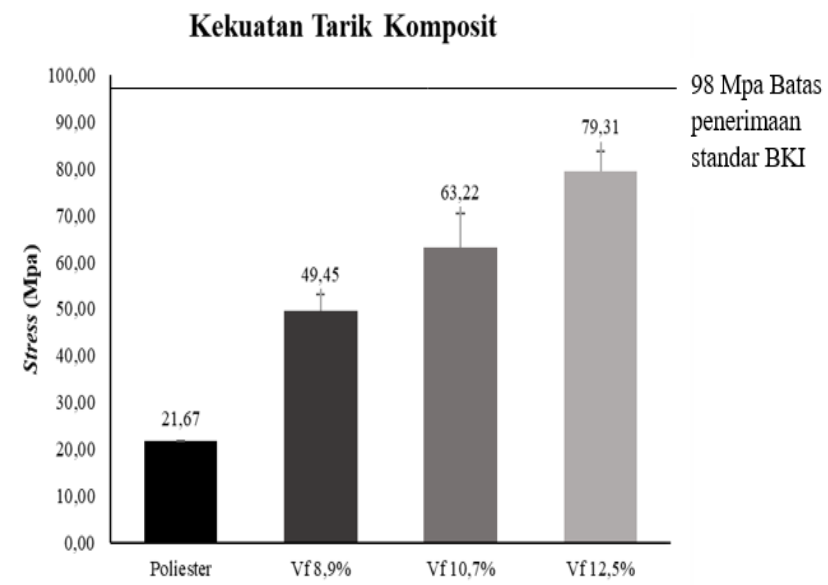

Gambar 16. Kekuatan tarik rata-rata komposit

Hasil data pada gambar 16 menyatakan bahwa semakin bertambahnya fraksi volume serat, maka kekuatan tarik pada komposit juga meningkat. Hal ini karena fraksi volume serat semakin bertambah sehingga kemampuan serat untuk menahan beban jauh lebih kuat. Orientasi serat yang digunakan yakni $0^{\circ}$ yang dimana orientasi ini memiliki arah serat yang searah dengan gaya pembebanan yang akan menghasilkan kekuatan tarik yang tinggi [25].

Faktor yang menyebabkan penurunan kekuatan yaitu void dan daerah kaya matriks. Void dapat mempengaruhi ikatan antar serat dan matriks karena void ini akan menimbulkan celah yang akan menyebabkan matriks tidak mampu mengisi ruang kosong pada cetakan. Ketika komposit mendapatkan pembebanan, tegangan akan berpindah pada daerah void dan mengakibatkan kekuatan pada komposit tersebut menurun [22] karena ikatan antar serat dan matriks tidak begitu kuat. Selain itu, terdapat daerah yang kaya matriks dimana terdapat minim serat yang kurangnya penguatan pada daerah tersebut [26]. Pada hasil gambar 15 , didapatkan perkiraan jumlah void pada komposit mencapai $2,73 \%$.
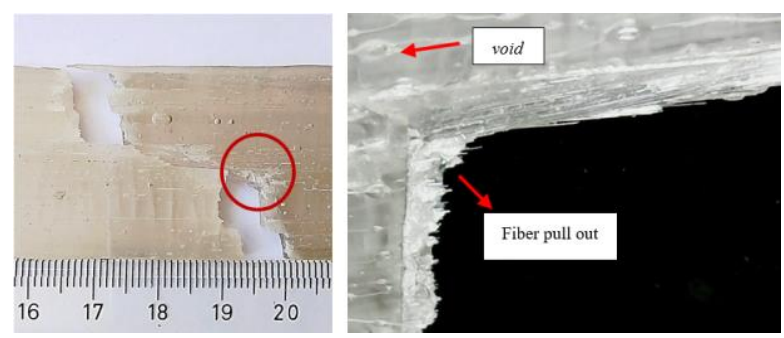

(a) 

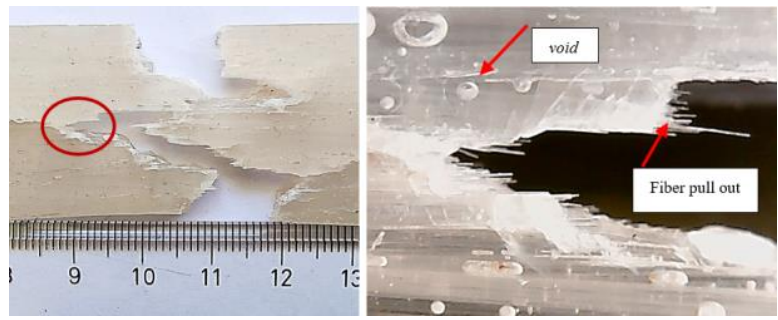

(b)
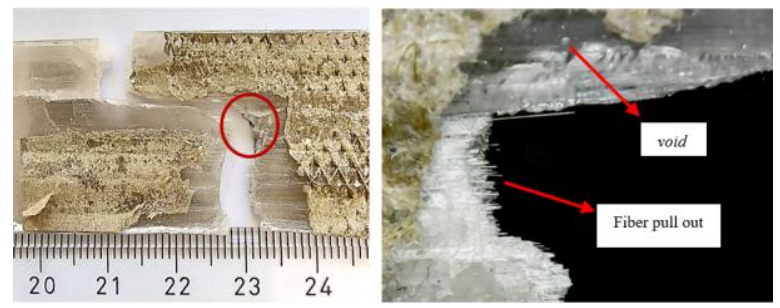

(c)

Gambar 17. Hasil patahan komposit (a) Vf 8,9\%, (b) Vf $10,7 \%$, (c) Vf $12,5 \%$

Pada gambar 17, hasil patahan dari uji tarik komposit yang dimana ikatan serat dan matriks masih terikat dengan baik namun terdapat void disekitar patahan komposit. Void inilah yang memicu terjadinya patahan. Selain itu, terdapat fiber pull out yang ditandai dengan serat yang keluar. Hal ini diakibatkan melemahnya ikatan matriks namun serat masih bisa menahan beban yang terima sehingga serat serat terlepas dari matriks [27].

\section{Pengujian Tekuk}

Dalam penelitian ini dilakukan pengujian tekuk, pengujian ini dilakukan untuk mengetahui nilai tegangan tekuk, regangan dan modulus elastisitas dari setiap variabel komposit. Pengujian dilakukan sebanyak tiga kali pengulangan setiap variable. Setelah pengujian dilakukan, berikut hasil data kekuatan tekuk rata-rata dalam bentuk diagram batang

Kekuatan Bending Komposit

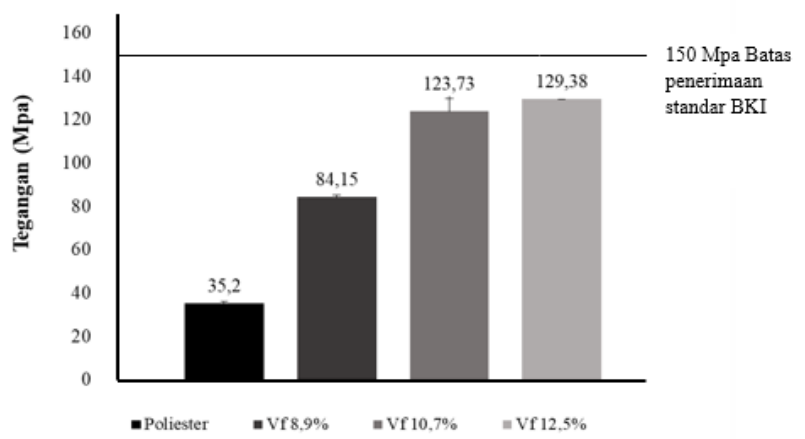

Gambar 18. Hasil patahan komposit (a) Vf 8,9\%, (b) Vf $10,7 \%,(c)$ Vf $12,5 \%$

Gambar 18 menjelaskan bahwa nilai kekuatan tekuk rata-rata pada spesimen polyester sebesar 35,202 $\mathrm{MPa}$, pada komposit dengan fraksi volume serat Vf $8,9 \%$ sebesar 95,364 $\mathrm{MPa}$, pada komposit dengan fraksi volume serat Vf $10,7 \%$ sebesar $123,733 \mathrm{MPa}$ dan pada komposit dengan fraksi volume serat Vf 12,5\% sebesar 129,38 MPa. Semakin bertambahnya fraksi volume serat maka semakin tinggi sehingga kekuatan tekuk komposit juga meningkat [11]. Arah serat dengan orientasi $0^{\circ}$ memiliki kemampuan menahan beban tekuk tertinggi, karena orientasi $0^{\circ}$ searah dengan gaya yang ditimbulkan oleh pembebanan tekuk [28].

\section{KESIMPULAN}

1. Semakin bertambahnya fraksi volume serat pada komposit fiberglass-polyester berpenguat serat gelas, kekuatan tarik dan tekuknya akan semakin meningkat. Kekuatan tertinggi terdapat pada komposit dengan fraksi volume serat $12,5 \%$ yaitu kekuatan tarik sebesar 79,31 MPa dan kekuatan tekuk sebesar 129,38 MPa Hal ini karena bertambahnya jumlah penguat komposit yang akan meningkatkan kekuatannya baik tarik maupun tekuk. Penelitian ini belum bisa digunakan sebagai penguat kapal karena belum memenuhi standar BKI.

2. Perkiraan kandungan void tertinggi terdapat pada komposit dengan fraksi volume serat $8,9 \%$ yaitu $2,73 \%$ dan yang terendah pada fraksi volume serat $12,5 \%$ yaitu sebesar $1,84 \%$.

\section{UCAPAN TERIMA KASIH}

Terima kasih kepada Laboratorium Terpadu Institut Teknologi Kalimantan atas bantuan peminjaman tempat dan peminjaman beberapa alat pengujian.

\section{REFERENSI}

[1] Ma'ruf, dkk., Teknologi pembangunan dan sertifikasi kapal SEP-Hull, Laporan Penelitian, BPPT, Jakarta, 2009.

[2] Ma'ruf, Buana, Studi standardisasi konstruksi laminasi lambung kapal fiberglass, Jurnal Standardisasi, Vol. 13, No. 1, 2011, pp 16-25.

[3] Setiawan, Andi Tri, dkk., Analisa sifat mekanik komposit serat gelas pada lapisan yang berbeda, ENTHALPY: Jurnal Ilmiah Mahasiswa Teknik Mesin. Vol. 4, 2019, pp 47-52.

[4] R.M. Christensen, Mechanics of Composites Materials, John Wiley \& Sons, Inc., New York, 1999.

[5] Hasbi, Muhammad, Aminur, Sahril, Studi sifat mekanik komposit polimer yang diperkuat partikel clay, Jurnal Ilmiah Mahasiswa Teknik Mesin, vol. 1, no. 1, 2016.

[6] F.L. Rawlings, Composite Materials: Engineering and Science, New York: CRC Press, 1999.

[7] M.M. Schwart, Composite Material Handbook, Mc Graw Hill, Singapore, 1984.

[8] R.F. Gibson, Principles Of Composite Material Mechanics, NewYork: McGraw-Hill, Inc, 1994.

[9] Kalpakjian, Serope, Manufacturing: Engineering and Technology, Pearson, NewJersey, 2010.

[10] F.C. Campbell, Structural Composite Materials, ASM International, Ohio, 2010. 
[11] Gundara, Gugun., Analisis fisis dan mekanis komposit serat gelas berlapis, Jurnal Teknik Mesin Universitas Muhammadiyah Tasikmalaya Jawa Barat, Vol, 2, 2017.

[12] P.K. Mallick, Fiber Reinforced Composites: Materials, Manufacturing, and Design Third Edition, Taylor \& Francis Group, 2007.

[13] Reis, João Marciano Laredo dos, José Luiz Cardosob, Protasio Ferreira e Castrob, Mechanical properties of recycled kraft paper residue polyester composites, Ibero-american Journal of Materials, Mat. Res. 17 (4), 2014, doi: 10.1590/S1516143920140005000086.

[14] L. Prabowo, Pengaruh perlakuan kimia pada serat kelapa (coil fiber) terhadap sifat mekanis komposit serat dengan matrik polyester, Skripsi, Yogyakarta: Universitas Sanata Dharma, 2007.

[15] A.C. May, Epoxy Resin Chemical and Technology, New York: Marcel Dekker Inc, 1998.

[16] M. Lee, Stuart., Handbook of Composite Reinforcements, California: VCH Publishers, 1993.

[17] D.R. Askeland, The Science and Enginnering of Material, Alternate Edition, PWS. Engineering, Boston, USA, 1985.

[18] W. Callister, Materials Science and Engineering, New York: McGrawHill, 2014.

[19] ASTM D790-03, Standard Tets Method for Flexural Properties of Unreinforced and Reinforced Plastic and Electrical Insulating Material, ASM International.

[20] ASTM D2734-94, Standard Test Methods for Void Content of Reindorced Plastic, ASM International.

[21] [BKI] Biro Klasifikasi Indonesia

[22] Saidah, Andi., Sri Endah Susilowati, Yos Nofendri, Pengaruh fraksi volume serat terhadap kekuatan mekanik komposit serat jerami pada epoxy dan serat jerami padi resin yukalac 157, Jurnal Konversi Energi dan Manufaktur UNJ, vol. 5, no.2, 2018, doi: 10.21009/JKEM.5.2.7.

[23] Asroni, Deni Nurkholis, Pengaruh komposisi resin polyester terhadap kekerasan dan kekuatan traik komposit papan partikel onggok limbah singkong. Jurnal Teknik Mesin Universitas Muhammadiyah Metro, Vol. 5, No. 1, 2016.

[24] Jatmiko, Agus. dkk., Alat wet lay up terkontrol sederhana dan analisis pengaruh proses lay up terhadap sifat mekanik material komposit, $e$ Proceeding of Engineering, Vol. 4, No. 1, April 2017.

[25] Munasir, Studi pengaruh orientasi serat fiber glass searah dan dua arah single layer terhadap kekuatan tarik bahan komposit polypropylene, Skripsi, Universitas Negeri Surabaya, 2011.

[26] Sunardi, Heri. Achmad Zainuri, Agus Dwi Catur, Pengaruh tahapan proses pelubangan dan arah serat terhadap kekuatan tarik material komposit polyesterpandan wangi, Jurnal Dinamika, Vol. 3, No. 1, Januari 2013.

[27] A.Y. Leiwakabessy, dkk., Perubahan sifat mekanis komposit hibrid polyester yang diperkuat serat sabut kelapa dan serat ampas empulur sagu, Rekayasa Mesin, vol. 4, no.3, 2013.

[28] A. Nurudin, A, Karakterisasi kekuatan mekanik komposit berpenguat serat kulit waru (hibiscus tiliaceus) kontinyu laminat dengan perlakuan alkali bermatriks polyester, Rekayasa Mesin, vol. 2, no 3, 2011. 